\title{
Hydrolysis of Dipeptides by Human and Ovine Placentas
}

\author{
SHARON S. CRANDELL, EUGENE W. ADCOCK, III, AND FRANK H. MORRISS, JR. ${ }^{(25)}$ \\ Houston Perinatal Nutrition Laboratory, Departments of Pediatrics and of Obstetrics and Gynecology, The University \\ of Texas Health Science Center at Houston Medical School, Houston, Texas, USA
}

\begin{abstract}
Summary
Human and ovine placental tissue homogenates were assayed for dipeptidase activity in vitro. Glycyl-L-leucine, L-leucyl glycine, glycyl-L-lysine, and L-lysyl glycine were hydrolyzed by placental homogenates. The $\mathrm{pH}$ optimum for the reaction was 8.0. The relationship between enzyme activity and concentration was linear for placental homogenate concentrations between 0.01 and 0.10 $\mathrm{mg}$ protein/ml of reaction mixture. Enzyme activities were 1.92 \pm 0.12 (S.E.) $\mu$ moles $/ \mathrm{min} / \mathrm{mg}$ protein for hydrolysis of glycyl-Lleucine, $0.34 \pm 0.06$ (S.E.) $\mu$ moles $/ \mathrm{min} / \mathrm{mg}$ protein for hydrolysis of glycyl-L-lysine by human placenta, and $2.79 \pm 0.80 \mu$ moles/ $\mathrm{min} / \mathrm{mg}$ protein and $0.41 \pm 0.25 \mu \mathrm{moles} / \mathrm{min} / \mathrm{mg}$ protein, respectively, by ovine placenta. The infusion of glycyl-L-leucine into the uterine artery of unstressed catheterized pregnant ewes yielded increased concentrations of both component amino acids in uterine venous blood and of leucine in umbilical venous blood.
\end{abstract}

\section{Speculation}

The presence of dipeptidase activity in placental homogenates and the observation that glycyl-L-leucine when infused into the main uterine artery is hydrolyzed to its component amino acids support the hypothesis that leucine and possibly glycine extracted from the placenta by the umbilical circulation may be provided by placental hydrolysis of dipeptides which arise within the placenta from the degradation of larger peptides and proteins.

During the last third of gestation, the sheep fetus accumulates nitrogen at approximately $0.65 \mathrm{~g} / \mathrm{day} / \mathrm{kg}$ body weight (17). Amino acids supply the nitrogen for fetal growth. and they also are utilized by the ovine fetus for gluconeogenesis (16). Amino acids may be utilized to meet the caloric needs of the fetus $(2,10)$. It is generally thought that maternal circulating free amino acids are the source of amino acids which are actively transported across the placenta to the umbilical circulation. Comparison of the ovine umbilical uptake of amino acids (10) with uptake of amino acids by the gravid ovine uterus (13) reveals, however, that a discrepancy exists between uterine and umbilical uptakes of certain amino acids. For example, the uptake of glycine by the gravid ovine uterus is not significantly different from zero, yet the umbilical uptake of glycine by a $2 \mathrm{~kg}$ fetus with an umbilical blood flow of $168 \mathrm{ml} / \mathrm{min} / \mathrm{kg}$ fetal weight is approximately $9.4 \mu \mathrm{moles} / \mathrm{min}$. A similar discrepancy exists for leucine. These data suggest that a source of amino acids other than maternal whole blood amino acids may provide some amino acids for the fetus.

It is known that amino acids are transported across the gastrointestinal mucosa as dipeptides as well as in the form of free amino acids. Dipeptides undergo carrier-mediated transport into the absorptive cells where they are hydrolyzed to their component amino acids which subsequently pass into the portal circulation
(11). Although there are no known dipeptides circulating in the normal human nor in sheep, the placentas of both species have well-documented proteolytic activities which could provide the trophoblast with a source of dipeptide (7). The purpose of this investitation was to examine the possibility that hydrolysis of dipeptides in the placenta might provide the free amino acids glycine and leucine which subsequently are extracted by the umbilical circulation.

\section{MATERIALS AND METHODS}

Placentas were obtained immediately after delivery and washed in cold normal saline to remove blood. Full-thickness sections of placenta $(2 \times 2 \mathrm{~cm})$ were placed in scintillation vials and promptly frozen on dry ice. The sections were stored at $-70^{\circ} \mathrm{C}$ until they were used within $4 \mathrm{wk}$ in the assays. Preliminary studies demonstrated no loss of enzyme activity when fresh homogenates were compared with frozen aliquots which were frozen for as long as 4 wk.

A crude enzyme extract was prepared by homogenizing a section of placental tissue in $20 \mathrm{ml}$ of cold normal saline. The homogenate was centrifuged at $10,000 \times g$ in a Beckman J-21B refrigerated centrifuge for $30 \mathrm{~min}$. The supernatant was used as the enzyme preparation in the assay. The protein content of the enzyme preparation was determined using the Lowry method of protein analysis (9). The enzyme extract was adjusted to the appropriate protein concentration by dilution with cold normal saline.

The method used to determine enzyme activity was a modification of the fluorescent assay for proteolytic enzymes described by Schwabe (18) and Perrett et al. (15). Reaction mixtures of 200 $\mu$ l borate buffer $(0.15 \mathrm{M}, \mathrm{pH} 7.9), 100 \mu$ l enzyme preparation, and $100 \mu$ l substrate $(10 \mathrm{mM}$ solution of a selected dipeptide) were incubated in $5 \mathrm{ml}$ covered plastic tubes at $39.5^{\circ} \mathrm{C}$. At $0,5,10,20$, $40,60 \mathrm{~min}$ after initiation of the reaction, a tube was removed from the water bath, and the reaction was stopped by precipitating the enzyme protein with $3 \mathrm{ml}$ ethanol. All tubes were centrifuged at $10,000 \times \mathrm{g}$ for $30 \mathrm{~min}$. A $100 \mu \mathrm{l}$ aliquot of the supernatant was added to $2 \mathrm{ml}$ borate buffer $(0.2 \mathrm{M}, \mathrm{pH} \mathrm{6.0)}$. One $\mathrm{ml}$ of fluorescamine solution ( $15 \mathrm{mg}$ fluorescamine in $100 \mathrm{ml}$ acetone) was added to this mixture while vortexing. The fluorescence was read at $475 \mathrm{~nm}$ (excitation, $309 \mathrm{~nm}$ ) on a Turner fluorometer. Blanks and dipeptide standards were prepared in the same fashion. The rate of dipeptide hydrolysis was thus determined from the rate of decrease in fluorescence, which at $\mathrm{pH} 6.0$ is linearly correlated with the concentration of dipeptide present.

L-Lysyl glycine, glycyl-L-phenylalanine, L-leucyl glycine, glycylL-leucine, L-alanyl-L-alanine, L-alanyl glycine, glycyl-L-lysine, and lysyl-L-glycine were tested separately as possible substrates in the assay for dipeptidase activity. The assay was also carried out under the same conditions but substituting homogenized whole blood or normal saline for placental homogenate in the reaction to control for any change in fluorescence which might result from 
contamination of placental sections with blood or from spontaneous hydrolysis of the dipeptide during incubation.

Glycyl-L-leucine and glycyl-L-lysine were used as the substrates in subsequent assays to characterize and to quantitate enzyme activity in placental homogenates. To determine the optimum $\mathrm{pH}$ for the reaction, the activity for a given enzyme extract was measured at pH 6.0 to 9.0. The relationship between enzyme activity and concentration was studied by carrying out the reaction with enzyme extracts over a range of dilution $(0.01$ to $2.0 \mathrm{mg} / \mathrm{ml})$. When optimal assay conditions had been established, quantitative determinations, in duplicate, were made of glycyl-L-leucine and glycyl-L-lysine dipeptidase activity in tissue from 14 human placentas ( 12 full-term, appropriate for gestational age infants and two preterm, appropriate for gestational age infants) and three ovine placentas.

Leucine amino peptidase (LAP), which has a broad range of substrate specificity including glycyl-L-leucine and glycyl-L-lysine, has been reported to be present in placental tissue (6). The rate of hydrolysis for $\mathrm{L}$-leucyl peptides by this enzyme is maximum at $\mathrm{pH}$ 9.1 with activation by manganese ion (3). Under these conditions, the rate of hydrolysis of glycyl-L-leucine is one-tenth the rate of hydrolysis of leucine amide, a specific substrate for LAP (20). To establish that the dipeptide hydrolysis by placental homogenates observed in this study resulted from dipeptidase activity and not LAP activity, four separate assays were performed: (1) using leucine amide as the substrate and purified LAP as the enzyme preparation; (2) using glycyl-L-leucine as the substrate with purified LAP; (3) using leucine amide as substrate with the placental homogenate: and (4) using glycyl-L-leucine as substrate with the placental homogenate. The reaction conditions of these studies to distinguish dipeptidase from LAP activity were the same as those used in the assays for dipeptidase activity described above rather than optimal conditions for LAP activity.

The in vivo role of placental dipeptidase was examined using

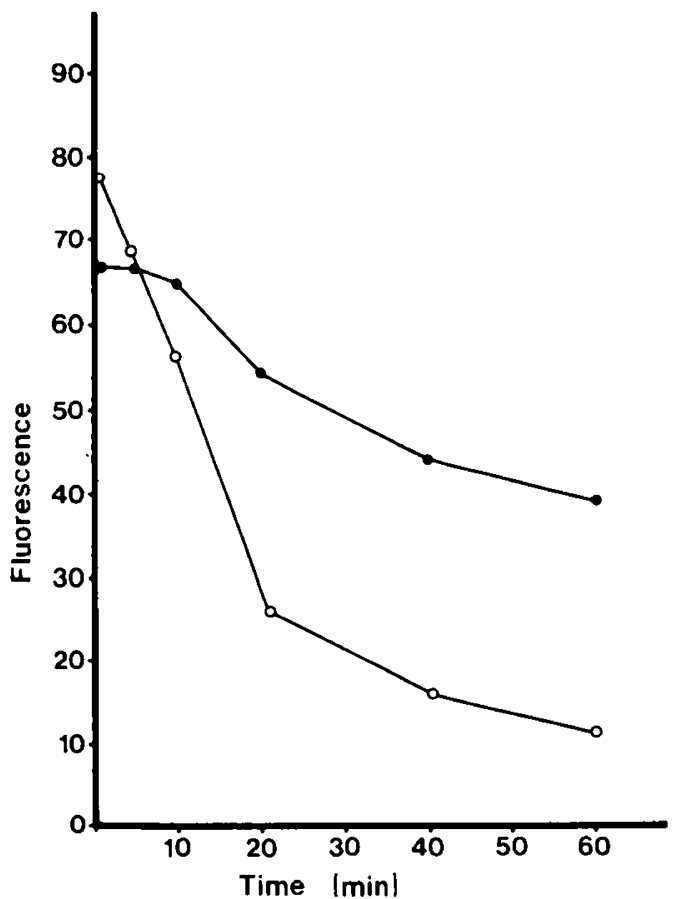

Fig. 1. Time course for hydrolysis of glycyl-L-leucine and glycyl-Llysine. Glycyl-I.-leucine and glycyl-L-lysine were incubated separately with a placental enzyme extract (protein concentration, $0.064 \mathrm{mg} / \mathrm{ml}$ ) at $39.5^{\circ} \mathrm{C}$. The rate of hydrolysis is represented by the rate of decrease in fluorescence from intact dipeptide during incubation. The hydrolysis of glycyl-L-leucine $(\mathrm{O})$, occurred more rapidly than the hydrolysis of glycyl-L-lysine (O).

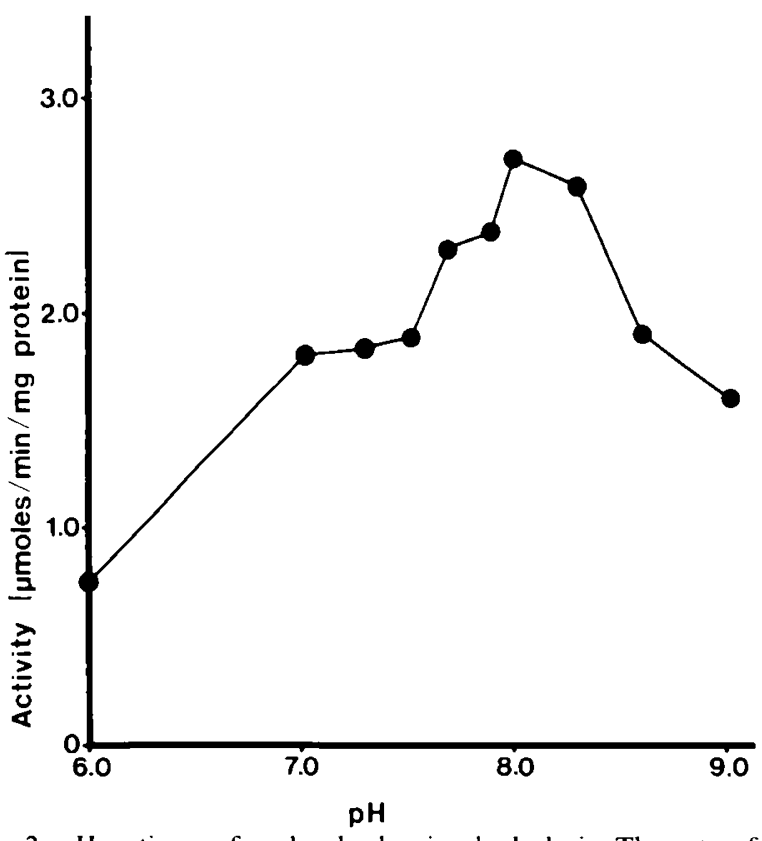

Fig. 2. pH optimum for glycyl-L-leucine hydrolysis. The rate of hydrolysis of glycyl-L-leucine was determined at $39.5^{\circ} \mathrm{C}$ at $\mathrm{pH} 6.0$ to 9.0 . The $\mathrm{pH}$ optimum for glycyl-L-leucine hydrolysis was 8.0 .

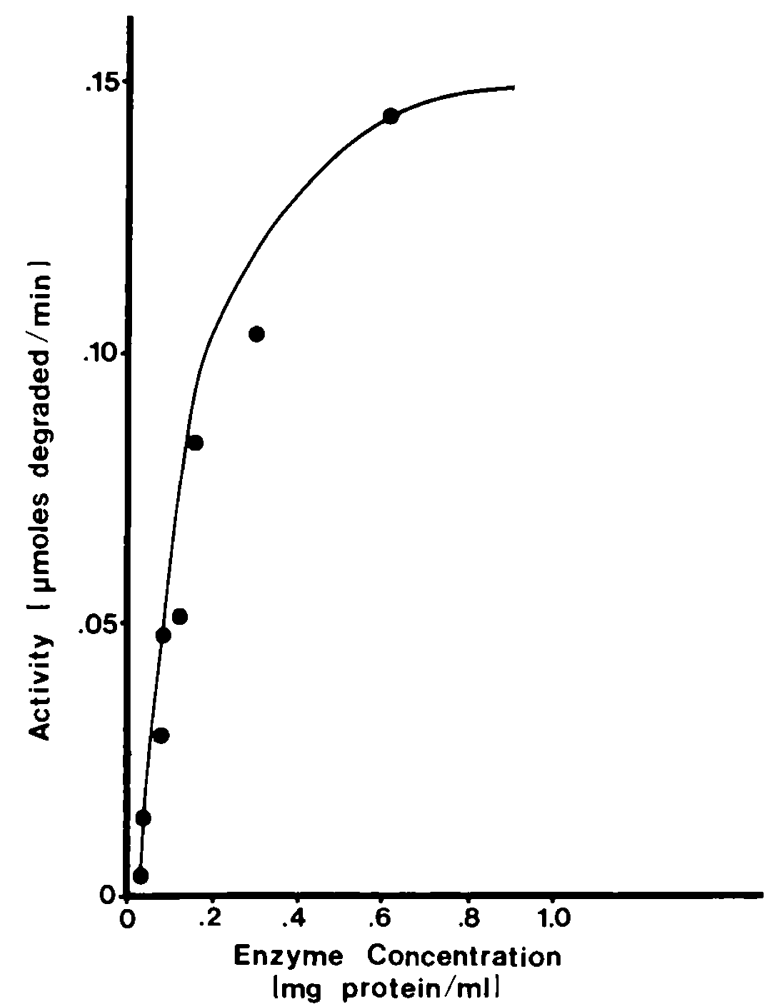

Fig. 3. Enzyme activity as a function of concentration of enzyme extract. The hydrolysis of glycyl-L-leucine was determined at $39.5^{\circ} \mathrm{C}, \mathrm{pH}$ 7.9. by enzyme extracts of increasing protein concentration from two different placentas (one represented by $O$, the other by $\bigcirc$ ). A linear increase in enzyme activity was observed for increasing enzyme concentration for $0.01 \mathrm{mg}$ protein per $\mathrm{ml}$ to $0.10 \mathrm{mg}$ protein $/ \mathrm{ml}$.

chronically instrumented pregnant sheep. Under spinal anesthesia. six ewes of 125 to 135 days gestation had indwelling catheters placed in the maternal femoral artery, one uterine artery, and directly in the umbilical vein. After a control period during which 
saline was infused into the uterine artery, a solution of glycyl-Lleucine in saline was infused into the uterine artery for 30 to 60 $\mathrm{min}$. The following concentrations and rates of infusion were used: $5 \mathrm{mM}$ solution at $0.2 \mathrm{ml} / \mathrm{min}$ (one ewe); $10 \mathrm{mM}$ solution at $1 \mathrm{ml} /$ min (one ewe); and $250 \mathrm{mM}$ at $1 \mathrm{ml} / \mathrm{min}$ (four ewes). The whole blood amino acid concentrations in maternal femoral arterial blood and in umbilical venous blood were measured before, during and after infusion of the dipeptide. Each umbilical venous blood sample was analyzed also for the dipeptide concentration.

Four additional ewes were prepared with femoral artery, bilateral uterine vein, and unilateral uterine artery catheters $(5,12,14)$. Into these four ewes, a solution of glycyl-L-leucine $(200 \mathrm{mM})$ in normal saline was infused via the right main uterine artery at 1 $\mathrm{ml} / \mathrm{min}$ for $30 \mathrm{~min}$ after a control period during which saline was infused. The whole blood concentrations of amino acids were

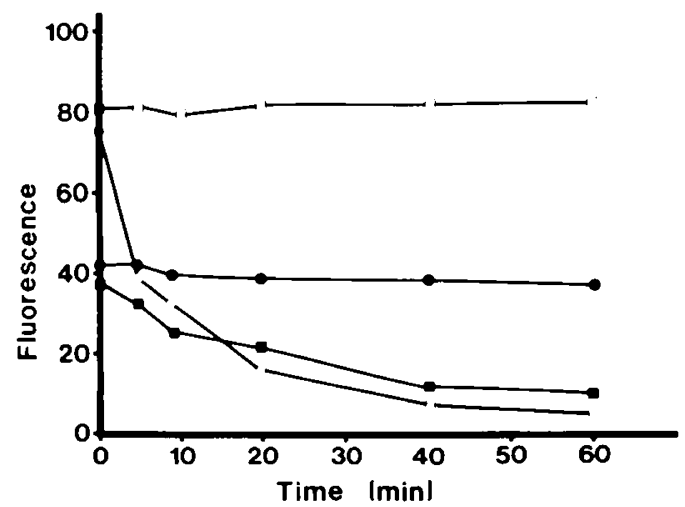

Fig. 4. Placental dipeptidase activity distinguished from placental LAP activity. At $\mathrm{pH} 7.9,39.5^{\circ} \mathrm{C}$, and with no activation by metal ions, the following assays were performed: (1) placental homogenate + leucine amide ( $\square$ ); 2) LAP + glycyl leucine (O): (3) homogenate + glycyl leucine (D): and (4) LAP + leucine amide (O). The placental homogenate rapidly hydrolyzed glycyl-L-leucine, but did not hydrolyze leucine amide. Purified LAP rapidly hydrolyzed leucine amide; however, glycyl-L-leucine was only minimally degraded by this enzyme. measured in blood from both uterine veins and from the femoral artery before the infusion, at 10 and $30 \mathrm{~min}$ after the initiation of the infusion and $30 \mathrm{~min}$ after the infusion was stopped. Each blood sample was analyzed also for the presence of the intact dipeptide glycyl-L-leucine.

Amino acid analysis was performed by column chromatography using a JEOL automated amino acid analyzer (13). The presence of dipeptide was detected by a quantitative gas liquid chromatographic/mass spectrometric method using glycyl-valine as a standard, a method which is sufficiently sensitive to detect dipeptide in $\mathrm{ng} / \mathrm{ml}$ concentrations $(19,24)$.

\section{RESULTS}

Of the dipeptides tested as possible substrates in the assay for dipeptidase activity, only L-lysyl-glycine, glycyl-L-lysine, L-leucyl glycine, and glycyl-L-leucine were hydrolyzed by human placental homogenates. Blood and saline controls consistently demonstrated no change in fluorescence after incubation for $60 \mathrm{~min}$. Glycyl-Lleucine was hydrolyzed more rapidly than was glycyl-L-lysine. The rates of hydrolysis of glycyl-L-leucine and L-leucyl glycine

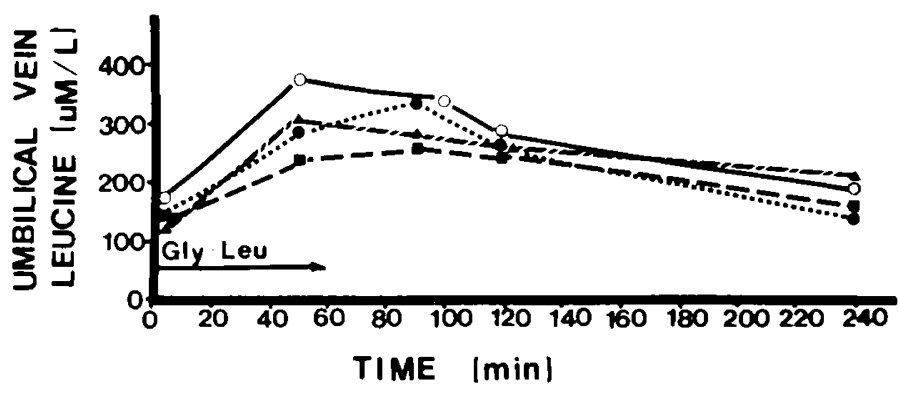

Fig. 6. Appearance of leucine in ovine umbilical venous blood in four fetal lambs subsequent to uterine artery infusion of glycyl-L-leucine ( 250 $\mathrm{mM}$ in normal saline at $1 \mathrm{ml} / \mathrm{min}$ for $60 \mathrm{~min}$ ). The whole blood concentration of leucine in umbilical venous blood increased during or after the infusion in each animal.

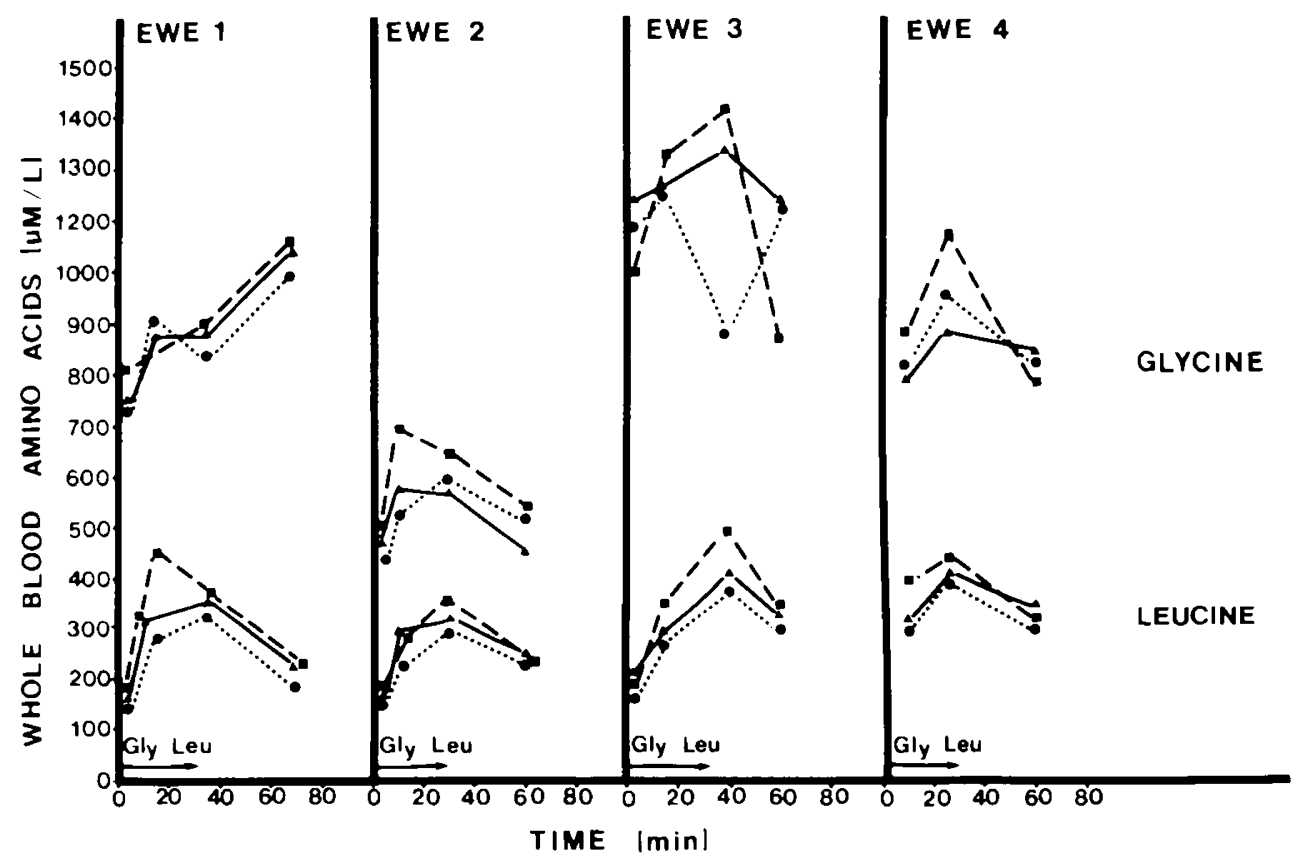

Fig. 5. Appearance of glycine and leucine in uterine venous blood after infusion of glycyl-t-leucine in normal saline $(200 \mathrm{mM}$ at $1 \mathrm{ml} / \mathrm{min}$ for 30 $\mathrm{min}$ ) into the right main uterine artery of each of four ewes. The whole blood concentrations of glycine and eucine rose in blood from the right uterine vein $(\square)$, the left uterine vein $(\boldsymbol{O})$, and the femoral artery $(\Delta)$. The increases were most pronounced in the right uterine venous drainage where the concentration exceeded the arterial concentration. 
were similar as were the rates of hydrolysis for lysyl-L-glycine and L-lysyl glycine. The time course for the hydrolysis of these two dipeptides is illustrated in Figure 1.

As illustrated in Figure 2, the $\mathrm{pH}$ optimum for hydrolysis of glycyl-L-leucine was 8.0. The $\mathrm{pH}$ optimum for hydrolysis of glycylL-lysine was similarly 8.0 . The rate of hydrolysis of glycyl-Lleucine by enzyme extracts from two different placentas correlated directly with the protein concentration of the enzyme extract within the range of 0.01 to $0.10 \mathrm{mg}$ protein $/ \mathrm{ml}$ extract (Fig. 3). At protein concentrations above $0.10 \mathrm{mg} / \mathrm{ml}$, the rate of reaction appeared to be substrate limited. The rate of hydrolysis of glycylL-lysine also directly correlated with the protein concentration of the enzyme extract over the same range of protein concentration.

For human placentas, the mean activity for glycyl-L-leucine hydrolysis was $1.92 \pm 0.12$ (S.E.) $\mu$ moles $/ \mathrm{min} / \mathrm{mg}$ protein, and the range was 1.30 to $2.93 \mu \mathrm{moles} / \mathrm{min} / \mathrm{mg}$ protein. The mean activity for glycyl-L-lysine hydrolysis was $0.34 \pm 0.06$ (S.E.) $\mu \mathrm{moles} / \mathrm{min} /$ $\mathrm{mg}$ protein; the range was 0.12 to $0.86 \mu \mathrm{moles} / \mathrm{min} / \mathrm{mg}$ protein. The enzyme activity of the preterm placentas was not significantly different from that of the full-term placentas. For the ovine cotyledonary tissue, the mean activity was $2.79 \pm 0.80$ (S.E.) $\mu \mathrm{moles} / \mathrm{min} / \mathrm{mg}$ protein for glycyl-L-leucine hydrolysis and 0.41 \pm 0.25 (S.E.) $\mu \mathrm{moles} / \mathrm{min} / \mathrm{mg}$ protein for glycyl-L-lysine hydrolysis.

Under the conditions used in this assay, purified LAP rapidly hydrolyzed its specific substrated leucine amide, illustrated in Figure 4 by the rapid decrease in fluorescence from intact leucine amide with time. The dipeptide underwent negligible hydrolysis by LAP. On the other hand, the placental homogenate significantly hydrolyzed the dipeptide as in previous experiments, but did not hydrolyze leucine amide. The enzyme activity in the placental homogenate thus appears to be dipeptidase activity unrelated to LAP activity.

The four animals prepared for the in vivo studies in which glycyl-L-leucine $(200 \mathrm{mM}$ at $1 \mathrm{ml} / \mathrm{min})$ was infused into the uterine artery each exhibited a rise in both femoral artery and uterine venous blood concentrations of glycine and leucine; however, the uterine venous concentrations of the amino acids were higher on the side of the uterus that was infused with dipeptide than the arterial concentrations (Fig. 5), indicating that the dipeptide was hydrolyzed in the placenta and that the component amino acids subsequently were released into the maternal uterine venous circulation.

Infusion of $5 \mathrm{mM}$ glycyl-L-leucine at $0.2 \mathrm{ml} / \mathrm{min}$ into the uterine artery of a pregnant ewe did not yield a detectable increase in umbilical venous blood concentration of the component amino acids. Pre- and postinfusion blood samples contained no detectable glycyl-L-leucine in either maternal or fetal blood. Infusion of $10 \mathrm{mM}$ glycyl-L-leucine at $1 \mathrm{ml} / \mathrm{min}$ into a second ewe was associated with a small increase in umbilical venous blood concentration of leucine from $172 \mathrm{mM} /$ liter to $211 \mathrm{mM} /$ liter; glycine concentration did not increase. As illustrated in Figure 6, however, infusion of $250 \mathrm{mM}$ glycyl-L-leucine at $1 \mathrm{ml} / \mathrm{min}$ in each of four ewes was associated with an increase in umbilical venous blood concentration of leucine. The umbilical venous blood concentration of glycine, however, was not consistently increased by the dipeptide infusion.
In the ewes infused with 200 or $250 \mathrm{mM}$ dipeptide solution at $1 \mathrm{ml} / \mathrm{min}$, none of the preinfusion samples contained detectable dipeptide in either maternal or fetal blood, and umbilical venous blood samples obtained during the infusion were found to contain no detectable dipeptide; however, maternal femoral arterial and uterine venous blood samples collected during the infusion contained detectable quantities of glycyl-L-leucine (Table 1). By 30 min after the infusion of dipeptide, the concentrations were negligible.

\section{DISCUSSION}

Vescia and Fidanza (21) and Zoch (23) reported the presence of dipeptidase activity in human placenta; however, neither investigator quantitated the activity, nor did either attempt to distinguish the reported activity from that of other enzymes known to degrade dipeptides. In this study, we have confirmed in homogenates of human and sheep placentas the presence of dipeptidase activity which hydrolyzes glycyl-L-leucine, L-leucyl glycine, glycyl-L-lysine, and L-lysyl glycine. This activity is not LAP activity. The $\mathrm{pH}$ optimum for placental glycyl-L-leucine dipeptidase, $\mathrm{pH} 8.0$, is similar to that reported for glycyl-L-leucine dipeptidase from pig intestine, $\mathrm{pH} 7.9$ (4). The observed rates of reaction for glycyl-Lleucine hydrolysis by placental homogenates are comparable to those reported for glycyl-L-leucine hydrolysis by homogenates of rat jejunum and ileum (8). We have thus shown that dipeptidase activity which is similar to that observed in gut is present in placental tissue.

The physiologic significance of placental dipeptidase activity in providing amino acids for the fetus remains speculative. The in vivo studies reported in this paper are consistent with the premise that the placenta can process certain dipeptides to amino acids. When glycyl-L-leucine was infused into the uterine artery of pregnant ewes, the whole blood concentrations of both leucine and glycine in uterine venous blood rapidly increased to become greater than the concentrations in the maternal arterial blood that perfused the placenta. Subsequently, leucine concentration increased in umbilical venous blood, suggesting that one of the components of the dipeptide is released by the placenta into the umbilical circulation. Glycine concentrations increased in the umbilical venous blood of each of the four ewes, but at such variable intervals during or after the dipeptide infusions as to be inconclusive. Leucine injected intravenously into pregnant ewes has been reported to appear rapidly in umbilical venous blood, in contrast to glycine, which does not (22).

Polypeptide nitrogen has been determined to be present in mammalian blood in amounts equal to 2.7 to $7.5 \mathrm{mg} / 100 \mathrm{ml}$ (1). The proportion of that polypeptide nitrogen which is present as dipeptide has not been reported. In our study, there was no detectable dipeptide in ovine blood prior to dipeptide infusion. A number of peptide-cleaving enzymes have been identified in placental tissue (7). We speculate that these peptidases may degrade hormones and other polypeptide molecules to form dipeptides which could then be hydrolyzed to their component amino acids by placental dipeptidases. Amino acids could thereby be provided for fetal uptake and account in part for the observed discrepancy between uterine and umbilical uptakes of leucine and possibly glycine.

Table 1. Serum concentrations of glycyl-L-leucine before, during, and after uterine artery infusion of glycyl-L-leucine (200 $\mathrm{mM})$ at $1 \mathrm{ml} /$ min into the right uterine artery of two sheep

\begin{tabular}{lcccc}
\hline & \multicolumn{4}{c}{ Glycyl-L-leucine $(\mu \mathrm{g} / \mathrm{ml} \mathrm{serum})$} \\
\cline { 2 - 5 } & Pre-infusion & $10 \mathrm{~min}$ & 30 min & Postinfusion (30 min) \\
\hline Maternal femoral artery & 0 & $30.1 \pm 4.5^{1}$ & $27.0 \pm 7.9$ & $1.3 \pm 1.2$ \\
Right uterine vein & 0 & $85.1 \pm 18.3$ & $78.8 \pm 8.3$ & $2.2 \pm 1.1$ \\
Left uterine vein & 0 & $23.7 \pm 5.9$ & $52.1 \pm 20.5$ & $1.1 \pm 0.8$ \\
\hline
\end{tabular}

\footnotetext{
'Mean \pm S.E.; $n=$ five studies
} 


\section{REFERENCES AND NOTES}

I. Altmane, P. L., and Dittner, D. S.: Biology Data Book, Vol. 3, p. 1806-1807 (Federation of American Societies for Experimental Biology, Bethesda. MD 1974).

2. Gresham, E. L., James, E. J., Raye, J. R., Battaglia, F. C., Makowski, E. L., and Meschia, G.: Production and excretion of urea by the fetal lamb. Pediatrics, 50: 372 (1972).

3. Guilbault, G. G.: Handbook of Enzymatic Methods of Analysis. p. 137-138 (Marcel Dekker. Inc., New York, 1976).

4. Josephson, L., and Lindberg, T.: Intestinal dipeptidases. I. Spectrophotometric determination and characterization of dipeptidase activity in pig intestinal mucosa. Biochem. Biophys. Acta, 105: 149 (1965).

5. Killam, A. P., Rosenfeld, C. R., Battaglia, F. C., Makowski, E. L., and Meschia, G.: Effect of estrogens on the uterine blood flow of oophorectomized ewes. Am. J. Obstet. Gynecol., /15: 1045 (1973).

6. Kleiner, H., Wilkin, P., and Snoeck. J.: Localization of the steroid dehydrogenases and leucine aminopeptidase in the human placenta. Geburtsh. Frauenheilkd., 22: 986 (1963)

7. Klopper. A., and Diczfalusy, E.: Foetus and Placenta, p. 437-438 (Blackwell Scientific Publications, Oxford, 1959).

8. Krzysik. B. A., and Adibis. S. A.: Cytoplasmic dipeptidase activity of kidney, ileum, jejunum, liver, muscle, and blood. Am. J. Physiol., 233: E450 (1977).

9. Layne. E.: Spectrophotometric and turbidimetric method for measuring protein. Protein estimations with Folin-Ciocalteu reagent. Methods Enzymol., 2: 448 (1957).

10. Lemons, J., Adcock, E. W., III, Jones, M.D., Jr., Naughton. M. A., Meschia, G., and Battaglia, F. C.: Umbilical uptake of amino acids in the unstressed fetal lamb. J. Clin. Invest., 58: 1428 (1976).

11. Mathews, D. M., and Adibi, S. A.: Peptide absorption. Gastroenterology, 71: 151 (1976).

12. Meschia, G., Makowski, E. L., and Battaglia, F. C.: The use of indwelling catheters in the uterine and umbilical veins of sheep for a description of fetal acid-base balance and oxygenation. Yale J. Biol. Med., 42: 154 (1969).

13. Morriss, F. H., Jr., Adcock, E. W., III, Paxson, C. L., Jr., and Greeley, W. J., Jr.: Uterine uptake of amino acids throughout gestation in the unstressed ewe. Am. J. Obstet. Gynecol., 135: 601 (1979).

14. Paxson, C. L., Morriss, F. H., and Adcock. E. W., III.: Effect of uterine artery insulin infusion on umbilical glucose uptake in sheep. Pediatr. Res.. 12: 864 (1978).

15. Perrett, D., Webb, J. P. W., Silk, D. B. A., and Clark, M. L.: The assay of dipeptides using fluorescamine and its application to determining dipeptidase activity. Anal. Biochem., 68: 161 (1975).

16. Prior, R. L., and Christenson, R. K.: Gluconeogenesis from alanine in vivo by the ovine fetus and lamb. Am. J. Physiol., 233: E462 (1977).

17. Rattray, P. V., Garrett. W. N., East, N. E., and Hinman, N.: Growth, development and composition of the ovine conceptus and mammary gland during pregnancy. J. Anim. Sci., 38: 613 (1974).

18. Schwabe, C.: A fluorescent assay for proteolytic enzymes. Anal. Biochem., 53 484 (1973).

19. Seifert, W. E., McKee, R. E., Bechner, C. F., and Caprioli, R. M.: Characterization of mixtures of dipeptides by gas chromatography/mass spectrometry. Anal. Biochem., 88: 149 (1978)

20. Smith, E. L.. and Hill, R. L.: Leucine amino peptidase. In: P. D. Boyer, H. Lardy, K. Myrback: The Enzymes, Vol. 4, pp. 5I-52 (Academic Press, Inc., New York. 1960).

21. Vescia. A., and Fidanza, A.: The peptidases of human placenta. Boll. Soc. Ital. Biol. Sper., 24: 832 (1948)

22. Young, M., and McFadyen, I. R.: Placental transfer and fetal uptake of amino acids in the pregnant ewe. J. Perinat. Med., I: 174 (1973).

23. Zoch, E.: Uber de peptidasen-aktivitat der menschlichen placenta. Enzymologia 28: 325 (1965).

24. Dipeptide analysis was performed by the Analytical Chemistry Laboratory at The University of Texas Health Science Center at Houston under the direction of Richard Caprioli, Ph.D

25. Requests for reprints should be addressed to: Frank H. Morriss, Jr.. M.D. Department of Pediatrics. The University of Texas Medical School at Houston, P. O. Box 20708. Houston, Texas 77025 (USA).

26. This research was supported in part by grant number 1-552 awarded by The National Foundation-March of Dimes and by grant R01 HD11337 awarded by the National Institute of Child Health and Human Development. Dr Crandell was supported by Research Fellowship number 5 F32 HD05467-02 awarded by the National Institute of Child Health and Human Development.

27. Received for publication October 31,1978

28. Accepted for publication August 19, 1980. 